\title{
ラム波用電磁超音波センサを用いた 引っぱり試験中のオンサイト応力評価*
}

\author{
村 山 理 - *1, 三 角 和 広*2
}

\begin{abstract}
Development of a Non-Contact Stress Measurement System During Tensile Testing Using the Electromagnetic Acoustic Transducer for a Lamb Wave
\end{abstract}

Riichi MURAYAMA*3 and Kazuhiro MISUMI

\footnotetext{
${ }^{* 3}$ Department of Intelligent Mechanical Engineering, Fukuoka Institute of the Technology. 3-30-1 WaziroHigashi, Higashi-ku, Fukuoka-shi, Fukuoka, 811-0295 Japan
}

\begin{abstract}
In recent years, investigations into the changes in the microstructure during the processing of functional metal materials have been carried out by many researchers. Therefore, it is required that the change in the material characteristic during processing by a nondestructive evaluation method be evaluated. However, conventional technology has been restricted to a static material characteristic evaluation. For example, a strain gauge has the problem that it can influence the measurement conditions of the tensile test and can only evaluate the position at which the strain gauge is attached. We then tried to develop a non-contact stress measurement system for tensile testing using an EMAT with a Lamb wave as a first step for the material characterization evaluation during a mechanical testing. The EMAT measures the propagation time of a Lamb wave between the receiver and a transmitter during the tensile testing. The interval between the transmitter and the receiver of the first set is $10 \mathrm{~mm}$ and can move in the direction of the tensile load. In this presentation, the specifications of the measurement system and the evaluation results are reported.
\end{abstract}

Key Words : Stress, Acoustoelasticity, Lamb Wave, Tensile Test, Electromagnetic Acoustic Transducer

\section{1. 粕}

近年, 高機能材料の開発が進められており, その 為に加熱, 圧延等を実施している間の材料特性を才 ンタイムで評価できることが求められ始めている.

しかしながら, 従来の非破壊評価法はこの要求に応 えるに至っていない. 特に内部材質評価可能な超音 波法において，一般に用いられる圧電振動子型超音 波センサが接触媒質を必要とする接触型であるため, 材料開発試験に影響を与えないオンサイト評価が困 難であった.

そこで, 各種材料試験中のオンタイム材料特性評 価試験方法開発の為の第 1 ステップとして, 引っぱ り試験中の引つ張り訊験片内の応力分布をオンタイ ムで測定するシステムを検討した. 非破壊的な応力 評価方法として音弾性法がよく知られているが, 応 力による音速変化は極微小であるため, 圧電振動子 型超音波センサでは，センサ移動中に十分な測定精 度で応力を評価することはできなかった。

* 原稿受付 2005 年 9 月 5 日.

*1 正員, 福岡工業大学知能機械工学科 (811-0295 福岡市東 区和白東 3-30-1).

*2 福岡工業大学知能機械専攻.

E-mail : murayama @ fit.ac.jp
この課題を克服する手段として接触媒質を用いな い電磁超音波センサを用いて，板厚方向に伝播する 横波を利用する場合()，或いは板面方向に伝播する 表面 SH波を利用する場合(2)が報告されている.こ れらの手法に対して筆者等は，板厚方向に入射する 超音波モードでは，板厚により受信信号波形の位置 分解能或いは時間分解能が不十分な場合があること, また表面 SH波の場合は十分な感度で歪みゲージに 相当する大きさの電磁超音波センサの製作が将来的 にも困難であることが考えられる.そこで, 申請者 らは引つ張り方向に伝搬するラム波（薄板の場合）， 或いはレーリー波（厚板の場合）を用いれば, 歪み ゲージと同じ空間分解能を持ち, センサを移動させ ながら，オンサイトな応力評価が可能であると考え た.

\section{2. 音弾性法の基本原理}

材料が応力を受けた状態では, 微小な弾性率変化 が発生し, 超音波伝搬速度も変化する. この応力に よる音速変化の現象を音弾性現象と言い、式(1)で 表される. ただし元々の音弾性式には超音波が伝播 する材料の組織異方性の効果に起因する定数項が存 
在し、一般的に応力による音速変化よりも大きい值 を示すため、式(1)では材料に応力が付加されてい ない場合と、付加されている場合の音速差を表すこ とを前提としている. また式(1)中の $\mathrm{C}_{\mathrm{A}}(1 \mathrm{MPa})$ は音 弾性定数とよばれ，応力による音速変化率を表す ${ }^{(3)}$ (の. 図 1 (a)に示すような固定間距離を超音波が伝搬 する場合，その伝搬時間は式(2)で示される. この 状態で試験片に引っ張り荷重が加わったと考えると 式(1)で表わされる音速変化は極めて小さく, また 図 1 (b)に示すように超音波センサが試験片に固定 された状態では，試験片が延ばされることにより， 超音波伝搬距離も変化するため, 伝搬時間変化は式 (3)のように変化することになり，その影響は無視 できない. さらに, このような接触型センサでは, センサを移動させながらの測定が非常に困難であり， 歪みゲージを補完できる応力センサには不向きであ った. もし、センサ間距離が固定で、接触媒質の厚 み変化も考虑不要であれば、応力による音速変化は 式(4)のようになり、信頼性の高い応力評価が可能 になると考えられる。

$$
\begin{aligned}
& \Delta V=C_{A} \times V_{\text {solid }} \times \sigma \cdots \cdot(1) \\
& T_{1}=\frac{L}{V_{\text {solid }}}+\frac{D_{1}}{V_{\text {water }}} \cdots \cdot \cdot(2) \\
& \Delta T_{1}=\left(\frac{L}{V_{\text {solid }}}-\frac{L+\Delta L}{V_{\text {solid }}-\Delta V}\right)+\frac{D_{1}-D_{2}}{V_{\text {water }}} \\
& \cong\{(L+\Delta L) \times \Delta V\} / V_{\text {solid }}^{2}+\frac{D_{1}-D_{2}}{V_{\text {water }}} \\
& =\left\{(L+\Delta L) \times C_{A} \times \sigma\right\} / V_{\text {solid }}+\frac{D_{1}-D_{2}}{V_{\text {water }}} \\
& \Delta T_{2}=\left(L \times C_{A} \times \sigma\right) / V_{\text {solid }} \cdot \cdots \cdot(4)
\end{aligned}
$$

$L$ : Distance between the transmitter and the receiver

$\Delta L:$ Elongation of $\mathrm{L}$ in the tensile specimen $V_{\text {solid: }}$ Velocity without the stress into the specimen

$V_{\text {water }}$ Velocity without the stress into the specimen

$\Delta V$ : Velocity change due to the stress

\section{$\sigma$ : Stress}

$C_{A}$ : Acoustoelastic Constant

$T_{1}$ :Transit time traveling the distance between the transmitter and the receiver before loading $\Delta T_{1}$ :Change in the transit time after loading $\Delta T_{2}$ :Change in the transit time ignoring the variation of the traveling distance and the Couplant thickness

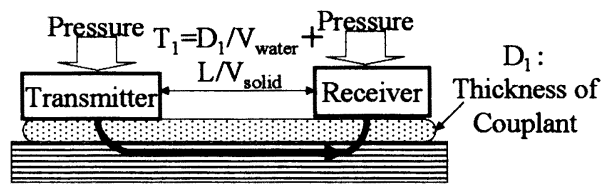

(a) Before tensile load

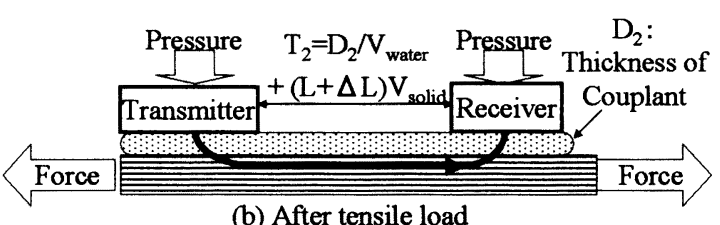

Fig. 1 Principle of acoustoelastic method

\section{3. 開発システムの特徵}

音弾性法をオンサイトな応力評価に適用する場合 の課題を解決する方法として, 図 2 に示す非接触超 音波センサを適用する事を考えた。この場合は，固 定治具を用いれば，送受信センサ間の距離もセンサ 前面と試験片表面の距離も不変となる.

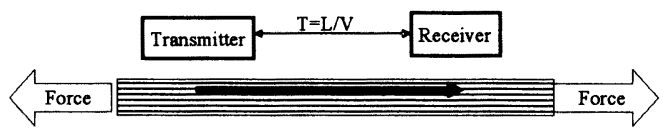

Fig.2 Merit of non-contact ultrasonic sensor

実際に使用する超音波モードは，板厚方向に縌波 或いは横波を伝搬させる場合と引つ張り応力方向に 伝搬するガイド波が考えられたが，板厚方向に伝搬 させる場合, 試験片厚が薄くなると受信信号の弁別 が極めて困難になること，伝搬時間が短くなり応力 による伝搬時間変化が検出できなくなること等の短 所が考えられた. ガイド波の場合, 送受信間距離を 固定すれば，受信信号の弁別は常に可能である. ま た板厚が薄く、引つ張り荷重による板厚変化を原因 とする音速変化が応力変化による音速変化より十分 小さい場合はラム波, この条件が成立しない厚さの 板厚の場合はレーリー波を適用することで板厚の影 
響は考慮する必要が無く，汎用性の高い測定システ ムの試作が可能であると考えた。

\section{4. 開発センサの概要}

本報告では，まずはガイド波が適用可能な薄板 (2mm以下) 引つ張り訊験片の応力評価に狙いを 絞ることとした。 また低周波領域のガイド波として は $\mathrm{S} 、 \mathrm{~A}_{0}$ モードの 2 種類のモードが存在するが、 板厚変化に対する速度分散性の小さい $\mathrm{S}_{0}$ モードを 利用することとし、 $\mathrm{S}_{0}$ モードーラム波用電磁超音

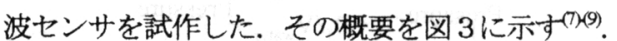

$\mathrm{S}_{0}$ モードーラム波は低周波数領域では、主に進 行方向に振動成分を持つため, 進行方向に周期的に 繰り返し応力を発生させる構造となっている.すな わち，鋼板表面にラム波進行方向に静磁場を負荷し， それに重冨させるようにセンサコイルに高周波波の バースト型パルス信号を与える事て鋼板表面に誘導 磁場をラム波進行方向に与える. その結果, 重胃磁 場の周期的変動が発生し, それに応じて磁性材料で ある鋼板は磁わい振動が生じる. そして, 図 3 に示 すセンサコイルの電極間間隔(W)がラム波の波長と 合致する駆動条件を与えることでラム波が発生する. 受信センサは, その逆の原理で伝搬してきたラム波 を受信する事ができる．また送受信センサ間距離は, $10 \mathrm{~mm}$ とし，センサコイルの各電極長も $10 \mathrm{~mm}$ とす ることで $10 \mathrm{~mm}$ 四方の平均応力を評価できる構造と した. なお、この電極長は試験片の最小幅の 0.5 倍 となっている. またセンサコイルの各電極の間隔 (W)は約 $1 \mathrm{~mm}$ として波長 $2 \mathrm{~mm}$, 駆動周波数 $2.5 \mathrm{MHz}$ のラム波を送受信するようにした。

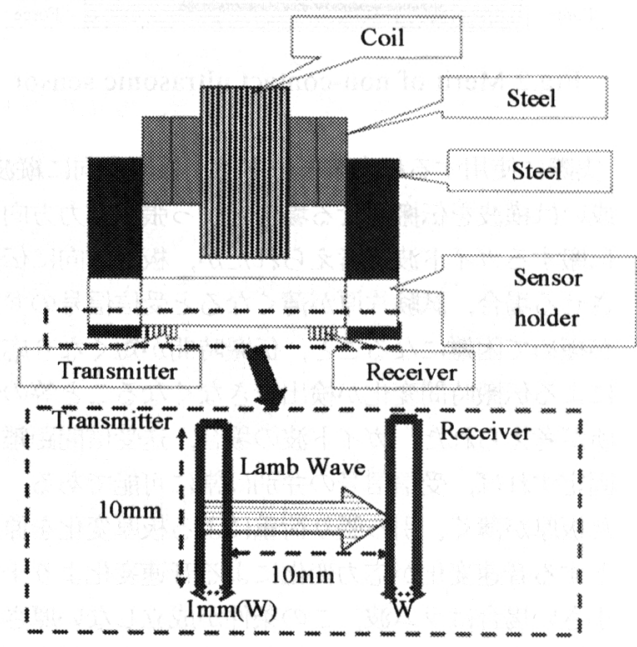

Fig. 3 Outline of a trial EMAT for a Lamb wave
5. オンサイト応力評価システム

$10 \mu \mathrm{m}$ の位置分解能を有する引つ張り方向 1 次元 走查機と伝搬時間評価ロジックを組み合わせる事に より, 開発した測定システムは引っ張り試験中に引 つ張り圾験片軸方向の任意の位置の $10 \mathrm{~mm}$ （電極長 さ） $\times 10 \mathrm{~mm}$ （送信センサと受信センサ間距離）範 囲の平均応力分布を土10MPaの精度で評価すること を目標とした. 1 次元走查機は可動距離 $110 \mathrm{~mm}$, 走查速度 $0.32 \mathrm{~mm} / \mathrm{s} \sim 0.38 \mathrm{~mm} / \mathrm{s}$ の性能を有しており, 試験片とセンサ前面との距離は $0.5 \mathrm{~mm}$ になるよう に配置した．また超音波センサを駆動するパルサは トーンバースト型で今回は正弦波形を 2 波分発信さ せ，送信信号電圧は $700 \mathrm{~V}$ に設定した。受信器は増 幅帯域が $500 \mathrm{kHz} \sim 5 \mathrm{MHz}$ で，増幅率は $60 \mathrm{~dB}$ とした。

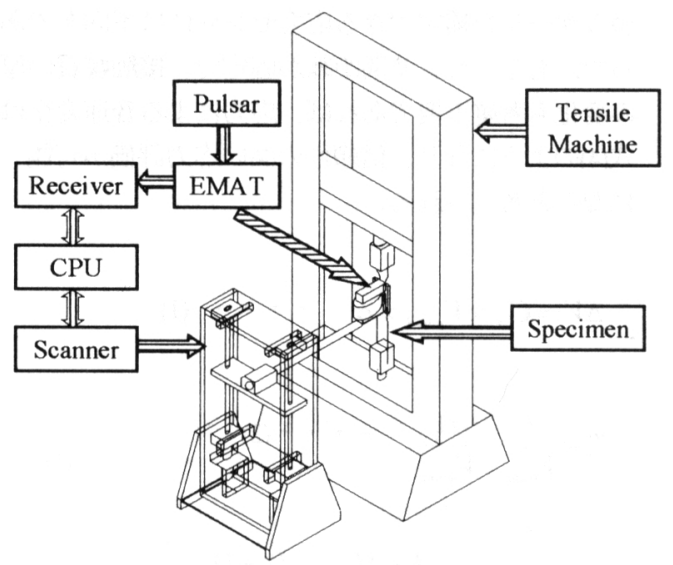

Fig. 4 Experimental System

$10 \mathrm{~mm}$ の間隔で設置された送信子，受信子間を伝 搬するラム波伝搬時間は，約 $2 \mu \mathrm{s}$ で，音弾性係数 が約 $10^{-5} \mathrm{MPa}$ だとすると，10MPaあたり 0.2nsの変 化量となる. この変化量を正確に再現性良く測定寸 る事は極めて困難であるため，精度の高い測定法と して図 5 に示すように，付加前に同一位置の伝搬時 間を評価し, 応力負荷時の変化を測定する方式とし た.この方式は試験片温度 (雰囲気温度) や材料の 初期異方性の影響を除去する効果もある。また試験 片の板厚が異なった場合でも，差を取る事で影響を 除去できる．但し、オンサイト出力の実用性を損な っているとも考えられるが、現状、オフラインでの 1 測定点当たりの解析時間は数秒程度であり、専用 の信号解析システムを構築する事で実用性はかなり 改善できると考えている．次に.付加前同一位置の 受信信号波形と負荷後の受信信号波形のスタート時 
間を遅延させながら式(5)に示す相互相関計数 $G_{x y}$ を算出し，その相互相関係数が最大になる遅延時間 を伝搬時間変化として評価した. 同一点で負荷荷重 を変えていった場合に、負荷荷重に対して伝搬時間 が比例すると考え、その場合の測定值のばらつき

（標準偏差）を評価すると、0.8nsであった.

$F_{1}(t)$ : Digitized waveform before loading

$\mathrm{F}_{2}(\mathrm{t})$ : Digitized waveform after loading

t: time

$\Delta \mathrm{t}$. Digitized time interval

$\tau:$ Delayed time $=\mathrm{k} \times \Delta \mathrm{t}$

$x_{i}$ : Signal amplitude at the order of $i$ in $F_{1}(t)$

$y_{i}$ : Signal amplitude at the order of $i$ in $F_{1}(t)$

$k$ : Shift mumber of the sampling data

$n$ : Totalnumber of the sampling data

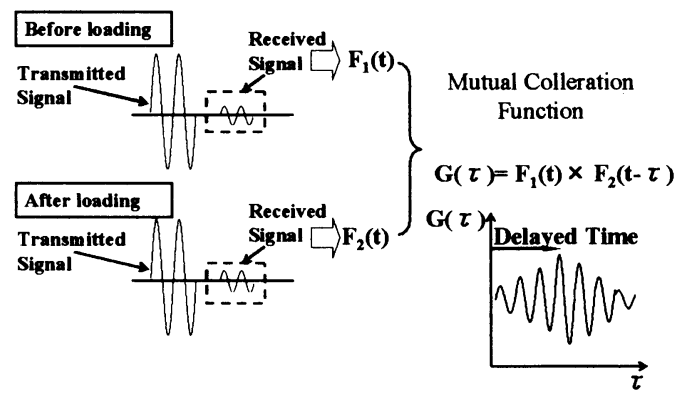

Fig.5 Transit Time Measurement Method

$$
G_{x y}(k)=\frac{\frac{1}{n} \sum_{i=1}^{n} x_{i} y_{i-k}}{\sqrt{\frac{\sum_{i=1}^{n} x_{i}^{2}}{n} \sqrt{\frac{\sum_{i=1}^{n} y_{i}^{2}}{n}}}} \cdots(5)
$$

\section{6. 実鈳条件}

開発中のシステムで応力測定を行うための応力評 価実験用の試験片を作成した. 作成した試験片を図 6 に示寸. 試験片の材質は純度 $99.5 \%$ の純鉄である. 板厚は $0.5 \mathrm{~mm}$ とした. この試験片は両端に試験機 によるつかみの部分を持ち, 通常の引張り試験片と は異なっている. 上部の試験片 $\mathrm{A}$ 型は, 引っ張り 時に試験片上下で非対称な応力分布が発生するよう に作成した. また下部の試験片 B型は，引っ張り 試験時に，試験片中央で対称な応力が発生するよう に製作した.

また引っ張り試験機は JTトーシ（株）製の卓上 試験機ミドルセンスター（最大引つ張り荷重 10kN）を用いた.

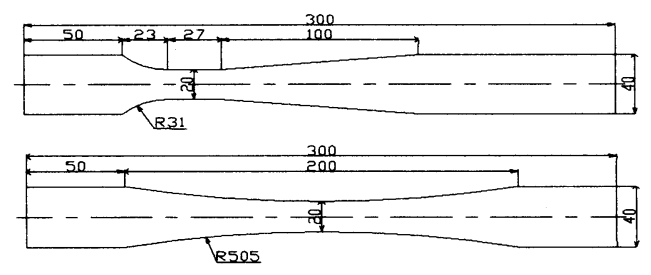

Fig. 6 Tensile Specimen

\section{7. 板厚変化の影暃}

引つぱり試験中の板厚変化による音速変化につい ては, 板厚変化量が塑性歪み以下の最大負荷応力 がかかったとしても $0.1 \mu \mathrm{m}$ 以下であることを実測 した. 図7は式(6)を使って， $\mathrm{S}_{0}$ モドラム波の場合の 板厚変化に対する音速変化を計算した結果である. $0.1 \mu \mathrm{m}$ 以下の板厚変化を音速変化に換算すると 5 $\times 10^{6}$ 以下となり，応力による音速変化に換算する と 5MPa程度となった. すなわち開発システムが 目標としている応力評価には殆ど影響しないこと を確認した.

$V=V_{0}\left[1-\left\{\frac{\lambda}{\lambda+2 \mu}\right\}^{2} \frac{(k d)^{2}}{3}\right] \cdots(6)$

$\mathrm{V}_{0}$ : Elementary Velocity

$\lambda, \mu$ : Lame Constant

d: Plate Thickness

k: Wavenumber

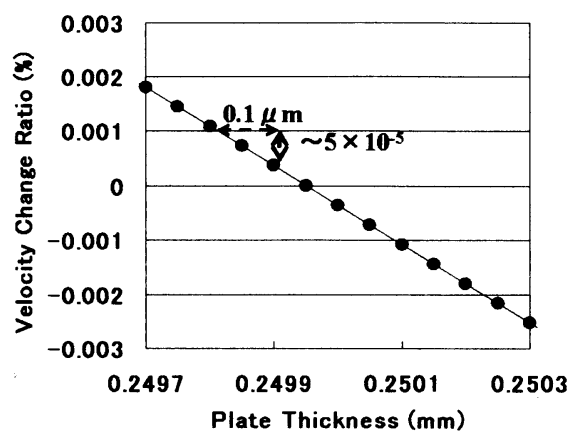

Fig.7 Relationship between the plate thickness and the change in the velocity

\section{8. 実験結果}

図 8(aに引つ張り試験片に応力を負荷していない場 合と負荷している(400MPa)状態での, 受信信号波形 例を示している. 応力が負荷されている圾験片で, わ ずかに伝搬時間が増加（音速が低下）していることが 
わかる. 図 8(b)に，この2個の波形に対して相互相関 法を適用した遅延時間と相互相関係数の関係を示す. この結果から 8ns の伝搬時間遅延があったことがわか る.

図 9 に段階的に負荷応力を変えていった場合の, 遅 延時間と負荷応力の関係を示す. 試験片 $\mathrm{AB}$ 型各々 について 5 枚用意し, 静止状態, 移動中 $0.32 \mathrm{~mm} / \mathrm{s}$, $0.38 \mathrm{~mm} / \mathrm{s}$ の条件で実験を行った．遅延時間測定値の バラツキ度は $0.5 \%$ 以下であり，静止状態，移動中の 測定値に有意差は無かった.この測定値より音弾性定 数を $731 \pm 0.05 \times 10^{6}(\mathrm{MMPa})$ と評価した. 遅延時間值加 ら応力値の換算は，全てこの評価した音弾性定数值を 用いた。

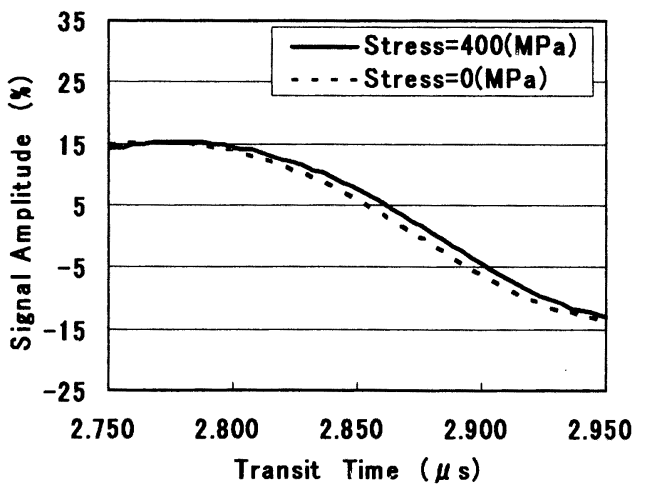

(a) Direct received signal

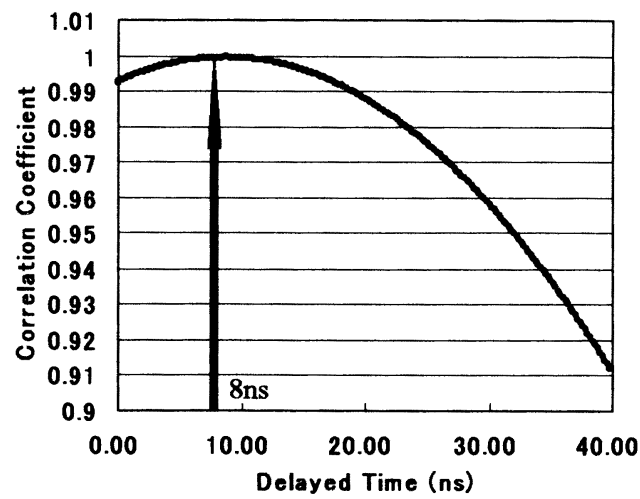

(b) Cross Correlation Function

Fig.8 Example of a transit time measurement

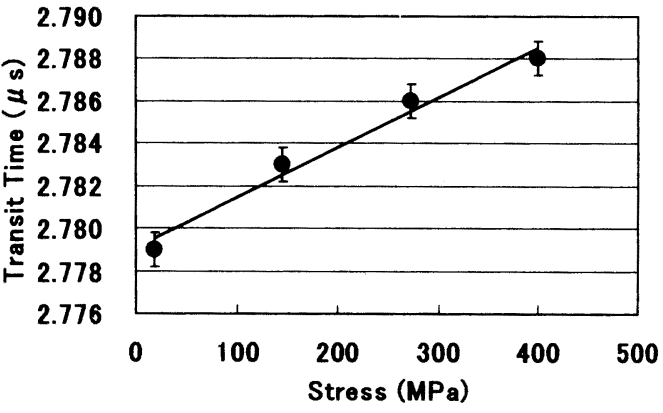

Fig.9 Relationship between the stress and the transit time

図 10 は A型試験片を用いて引つ張り応力方向の試 験片内の応力分布を評価した例である. 引つ張り荷重 を試験片断面積で割った応力計算值と超音波に評価し た忘力值は良く一致しており標準偏差は $12 \mathrm{MPa}$ であ った. 但し, 引っ張り試験片中心部に対して, 引っ張 り訊験片端部で，測定值と計算值のずれが大きくなる 傾向が見られる.この理由は，末だ明らかにできてい ないが理想的なラム波は半無限板を伝搬する波であり, 本システムのセンサのように超音波ビーム幅（センサ 幅)が板幅に対して有限である場合，訊験片の板幅が 変化することにより，超音波ビーム幅/板幅が変化す ることが影響している可能性があり，今後の検討課題 である.

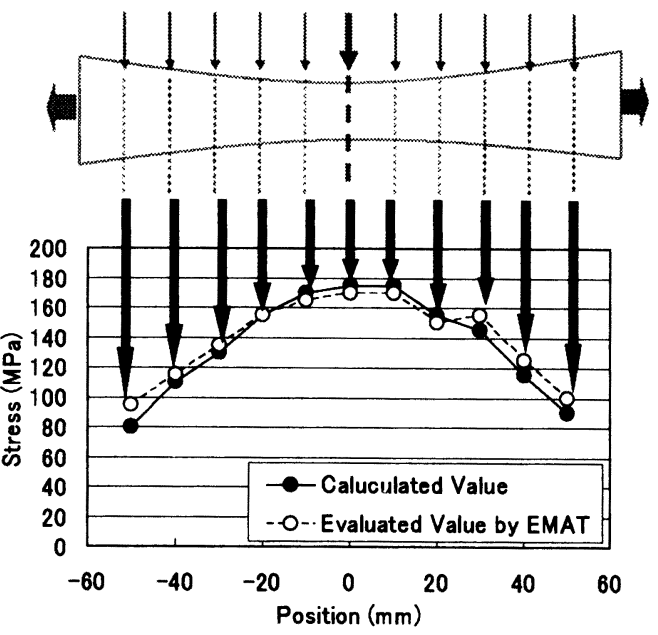

Fig.10 Example of evaluated value in Atype tensile specimen

図 11 はB 型試験片を用いて引つ張り応力方向の試 験片内の応力分布を評価した例である. ほぼ引つ張り 荷重に比例した超音波による応力評価值となっている. 
しかし測定位置 2，3 では負荷加重 350N，700N の結果 が逆転しており，また測定值 1,2 に対して測定位置 5,6 でも訊験片断面積に対応した応力変化に比べて 小さな変化しか示しておらず，A型試験片に比べて, 評価誤差が大きい結果となっている. 原因として, 試 験片形状が引つ張り方向の試験片中心に対して極端に 非刘称であるため, 中心から離れた位置では応力集中 が生じている可能性がある. また引つ張り訊験実施中 に試験片に加わる負荷そのものに偏りが生じている可 能性も考えられる. また図 10 の測定結果でも述べた が，ラム波のビーム幅に対して試験片幅が有限幅であ るため, 板幅が変化していくにつれてラム波発生条件 が変化している可能性も否定できない，今後，センサ 寸法の見直し，評価試験片形状の見直し再評価を進め る予定である.
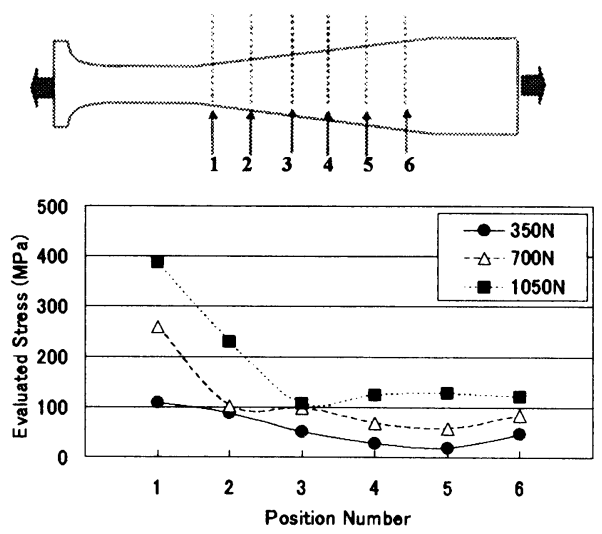

Fig. 11 Example of evaluated value in Atype tensile specimen

\section{9. まとめ}

オンサイトな材質評価システム開発のための第 1 段 として, 引っぱり試験中の詿験片一軸方向の応力分布 を評価するシステムを検討した. システムは $\mathrm{S}_{0}$ モー ドーラム波用電磁超音波センサを一軸方向に非接触 で移動させながら，相互相関法利用した高精度な音速 測定をおこなう方式を採用した。

評価訌験の結果, 試験片内の一軸方向応力分布を約 $10 \mathrm{MPa}$ の精度で評価する事が可能であった.

今後は，評価システムを 2 次元応力分評価が可能な ように改造する事と，板厚 $2 \mathrm{~mm}$ 以上に対応させるた めに表面波モード用電磁超音波センサも利用可能なシ ステムの改造を進めていく.

\section{文献}

(1)Toda et al.: Residual stress analysis using non-contact electromagnetic acoustic transducer, Transactions of the Japan Society of Mechanical Engineers, JSME Kansai Branch, The $60^{\text {th }}$ Conference, No.854-1, pp.65-67 (1985)

(2)M. Toda et al.: Stress measurement in thin plate using an EMAT, Transactions of the Japan Society of Mechanical Engineers, Series A, Vol.5, No.518, pp.2178-2183 (1989)

(3)D.I. Crecraft: The Measurement of Applied and Residual Stress in Metals using Ultrasonic Waves, J. Sound and Vibration, Vol.5, pp.173192 (1967)

(4)M. Hirao et al.: Non-Destructive Evaluation of Hardening Depth using Surface-Wave Dispersion Patterns, Journal of .Mechanical Working Technology., Vol.8, pp.171-179 (1983) (5)K. Okada: Stress-Acoustic Relation for Stress Measurement by Ultrasonic Techniques, Journal of .Acoustical Society of Japan (E), Vol.1, pp.193-200(1980)

(6)Y.H. Pao et al.: Acoustoelasticity and Ultrasonic Measurement of Residual Stress, in Physical Acoustics, Vol. X, VII, eds. W.P.Mason and R.N.Thurston, pp.61-143, Academic Press (1984)

(7).B. Thompson: A Model for the Electromagnetic Generation and Detection of Rayleigh and Lamb Wave, IEEE Transactions., SU-20, pp.340-346 (1973)

(8). B. Thompson: Mechanisms of Electromagnetic Generation and Detection of Ultrasonic Lamb Waves in Iron-Nickel Alloy Polycrystals., Journal of Applied Physics, Vol.48, pp.4942-4950 (1979).

(9)T. Yamasaki et al.: Generation and detection of $S_{0}$ mode Lamb wave using electromagnetic acoustic transducers. Proceeding of the 1994 Far East Conference on NDT, pp.87-94 (1994). 